J O U R N A O F French and Francophone Philosophy
RE V UE DE LA

philosophie française et de langue française

\title{
Irigaray's Alternative Buddhist Practices of the Self
}

Sokthan Yeng

Journal of French and Francophone Philosophy - Revue de la philosophie française et de langue française, Vol XXII, No 1 (2014) pp 61-75.

\author{
Vol XXII, No 1 (2014) \\ ISSN 1936-6280 (print) \\ ISSN 2155-1162 (online) \\ DOI $10.5195 /$ jffp. 2014.643 \\ www.jffp.org
}

\section{(c) EY-NC-ND}

This work is licensed under a Creative Commons Attribution-Noncommercial-No Derivative Works 3.0 United States License.

\section{ULIS D-Sult}

This journal is operated by the University Library System of the University of Pittsburgh as part of its D-Scribe Digital Publishing Program, and is co-sponsored by the University of Pittsburgh Press 


\title{
Irigaray's Alternative Buddhist Practices of the Self
}

\author{
Sokthan Yeng
}

Adelphi University

\section{Introduction}

Luce Irigaray's critics charge that her attempt to carve out a space for nature and the feminine self through an engagement with Buddhism smacks of Orientalism. Associating Buddhism with a philosophy of nature can lead to feminizing and exoticizing the non-Western other. ${ }^{1}$ Because she relies more on lessons learned from yogic teachers than Buddhist texts or scholarship, her work seems to be an appropriation of Buddhist ideas ${ }^{2}$ and a critique of Western ideology ${ }^{3}$ rather than a reflection of Buddhist philosophy.

I trace Orientalist readings of Buddhism, including those of Irigaray, back to Hegel's influence on comparative philosophy. Indeed, her analysis of the feminine self and nature often seem more like a response to Hegel than an examination of Buddhist principles. Some scholars resist Hegel's reading by arguing that the Buddhist Absolute manifests in the indeterminately disjunctive and alternative versions of reality and self. Others suggest that the meaning of Buddhism can be found in examining its practices rather than its logic.

Like in the work of many Buddhist scholars, glimpses of Irigaray's break with Hegel can be seen precisely when she focuses on the practice of Buddhism rather than when she seeks to develop a cohesive theoretical and logical system concerning the subject and its relation to the whole. I suggest that Irigaray's insights about meditation could show a way to join the philosophy of disjunctive alternatives to the practice of Buddhism. By heeding Irigaray's call to cultivate both the individuated and relational selves, I explore the possible fruits of meditating on each alternatively. A close examination of meditation practices can also challenge the notion that Buddhists move too easily and quickly towards collectivism. Put in this context, Irigaray's work reveals a genuine engagement with Buddhism that draws out a useful technique for understanding the Buddhist worldview. 


\section{Hegel on the Buddhist Dialectic}

Hegel is a prominent source of Orientalist readings of Buddhism partially because his interpretation of Buddhism was so far-reaching in comparative thought. Nagarjuna, one of the foremost and influential Buddhist scholars, ${ }^{4}$ often came to be understood through the lens of Hegel. The emergence of the self and the role of negation are thought to be keys for interpreting Nagarjuna's dialectic, just as it is with Hegel's system. Conceptions about Buddhism are, therefore, still tied to Hegel even when scholars engage with prominent Eastern thinkers.

Markers of Orientalism in Hegel's philosophy are conspicuous and integral to his philosophy of World History. Hegel's description of Eastern cultures helped to support his ideas of superior European societies. In making these distinctions between cultures, Hegel was also better able to explain his dialectical model. Because those in the East-though recognizing some distinction between self and nature-do not follow this contradiction through, they represent the beginning of World History. ${ }^{5}$ For Hegel, the conflict between the individual and nature is fundamental for the passage into society and out of natural existence. If there is no inkling that the self can be in conflict with his natural environment, the subject cannot have a proper sense of identity or begin to shape the world according to his desires. For Hegel, Eastern peoples have a budding nature. "In the Asiatic race,...mind is already beginning to awake, separate itself from the life of Nature. But this separation is not yet clear-cut, not yet absolute." 6 The Eastern mind is conscious of a separation between self and nature but this separation is not embraced. Because an individual identity cannot be formed, Hegel concludes that Asians represent the first movement of World History but cannot progress any further because the contradiction between self and nature is not put into play.

According to Hegel, Buddhists perceive reality in an imprecise and confused fashion. Reality remains largely unfiltered for them. He suggests that Asians fail to progress through the dialectical process because the moments of separation between themselves and the world in which they live are filled not with reason but with magic and superstition. Reason can point to contradictions and help provide a means to reconcile conflicts in reality that push to a new understanding of reality. The tools that Hegel attributes to the Eastern mind lead them to dismiss or conjure away contradictions in reality through a mystical power. He states, "With reference to the character of the people who adhere to this religion, this substantiality involves an elevation above the immediate, singular consciousness as it presents itself in magic, where it is just the singular consciousness that is the power, [natural] desire, or a yet untamed savagery." 7 Unable to work through contradictions, they seek unity by eschewing logic and find refuge in the unexplainable.

Their world is not shaped by a rational process that plays itself out on the field of finite beings, as in the West, but, rather, by one being which cannot be understood and is detached from the desire of the individual. They have 
not realized determinate negation. "The skepticism that ends up with the bare abstraction of nothingness or emptiness cannot get any further from there, but must wait to see if something else comes along... But when on the other hand the result is conceived in terms of its truth namely as a determinate negation, a new form has thereby arisen..." 8 Because Asians cannot properly respond to the discrepancies between their own desires and the world, they are at a loss and their spirit is of empty negation. They cannot move forward to create out of the contradiction between self and nature. With no conception of how to move forward, they seek to sink back into nature and the un-individuated.

While Hegel's desire to fit Buddhism within his philosophical system of being contributes to his less than flattering portrayal of it, ${ }^{9}$ he nevertheless believed that there is something productive in such an idea of nothingness. Hegel saw Buddhist nothingness as a way towards grasping the "infinite nature of substance in its simplicity and its immediacy." ${ }^{10}$ He believes that Buddhists are stuck within natural consciousness that cannot progress towards Absolute Spirit, which further requires a negation of the individual. Yet Buddhist nothingness, for him, did not aim towards atheism but signaled an attempt to understand God as the Absolute. The Buddhist conception, in contrast to Hegel's, took the Absolute to be indeterminate. ${ }^{11}$ Hegel recognized the paradox within Buddhism: from nothing, comes everything. This attitude, for Hegel, transforms Buddhists into followers of the cult of nothingness, which calls practitioners to unite with the Absolute by receding into a nature that resists logical order. ${ }^{12}$ Their meditative practices reflect a nature religion that not only works towards a consumption of self, according to Hegel, but rather a total destruction of the self in order to return to a divine void. Difference does not enrich or substantiate the subject, as it does in Hegel's dialectical system. Instead, nothingness is real and indeterminateness is the goal.

\section{Hegel and Nagarjuna's Dialectic}

Despite Hegel's assertion that the Buddhist philosophy runs so contrary to his, many scholars find similarities between Nagarjuna and Hegel's dialectic, ${ }^{13}$ especially through the role of negation. Those who seek to distance Buddhist philosophy from Hegel's still seem to rely on his reading of Buddhism and even reinforce Hegel's notion that Buddhist culture is a cult of nothingness. Such readings may provide an alternative account of being but they do not challenge Hegel's understanding of Buddhism or ultimately break with Hegel's system. By using Nagarjuna's texts to uncover different formulations of logical unity, scholars continue to operate within a Hegelian (and Orientalist) reading of Buddhism.

Because Nagarjuna addresses the fundamental Buddhist precepts of the Four Noble Truths in his "Two Truths Doctrine," this theory provides a resource for understanding his view of existence. Within his pithy commentary, scholars find insights about the seemingly competing truths about the nature of the individuated self and the wholeness of reality. 
Conventional truth points to individuation of the self and all else that exists. Ultimate truth, however, suggests the interconnectedness of being. He writes: The Buddha's teaching of the Dharma is based on two truths: A truth of worldly convention and an ultimate truth. Those who do not understand the distinction drawn between these two truths do not understand the Buddha's profound truth. Without a conventional truth, the significance of the ultimate cannot be taught. Without understanding the significance of the ultimate, liberation is not achieved. ${ }^{14}$

Thinkers further mine this text to discern the relationship between conventional and ultimate truth in order to draw comparisons and contrasts with Hegel's dialectic of being.

Nagarjuna's phrasing can lead some to believe that he, much like Hegel, sought to show the path of consciousness as it moves from understanding the conventional truth of self as individuated to an understanding of an ultimate truth of a self that is connected to the whole. This reading of Nagarjuna mirrors Hegel's system because negation is the motor for the movement of consciousness in grasping higher truths. ${ }^{15}$ Indeed, such scholarship on Nagarjuna's "Two Truths Doctrine" often relays the importance of negation for reaching the second (and higher) truth. Conventional understandings of the self and the first truth are points of departure but this viewpoint is to be left behind in favor of one that recognizes the whole. Arriving at the second truth is only possible by negating the first truth. If Nagarjuna means to leave individual existence behind in favor of ultimate existence, then his dialectic is similar to Hegel's in that it moves only in one direction. ${ }^{16}$

The Two Truths, therefore, are thought to represent different paths for practitioners of varying skill levels. ${ }^{17}$ Contemplation on the first truth of independent being can be seen as a starting point for those who can only perceive the self as such. Greater investigation of the self would eventually lead to the existence of other independent selves and questions about the relationship between these purportedly independent beings. The second truth seems to be crafted for those with higher levels of consciousness. Nagarjuna's ultimate truth, under this rubric, is that which pushes beyond the physical and towards the necessary relationships between ideas and ways of understanding through concepts. Through this interpretation, consciousness in Buddhism, as in Hegel, shows again that mind flows one way, towards greater enlightenment. ${ }^{18}$

An alternate interpretation of Nagarjuna uses logic, or logical inconsistencies, to point towards the concept of emptiness and codependent origination of being. In this reading, the first truth should be understood as a pedagogical necessity for understanding the second of the two truths. ${ }^{19}$ Contemplation on the self as distinct being leads us to questions about other discrete beings and our connections to them. The relational self, conversely, is conceptually dependent upon the independent self. Only after recognizing the individuated self can the relatedness be understood. Both the individual 
and the relational self, much like all else, are empty of independent nature. The goal of the Middle Path, which neither denies nor affirms one truth (or self) over the other, is to show that the relationality - like everything else - is dependent on other things and conditions. Reflections on the nature of the independent self, as in Irigarayan philosophy, help us to understand the relational self. Nagarjuna's logic also makes connections between the concept of the individual and the concept of the relational self. He, in other words, emphasizes relationality rather than the relational self.

Thinking Nagarjuna in opposition to the Hegelian logic of unity, however, can result in reinforcing Hegel's idea that Buddhism is the cult of nothingness. Read in this manner, Nagarjuna worked to elucidate a Buddhist Negation of Being - as opposed to Hegel's Absolute. ${ }^{20}$ Nagarjuna not only negates the first truth and the existence of the individuated self but he also negates the existence of the second truth, the existence of the interconnected self. He negates existence in both forms, which leads to the Negation of Being. There is, then, no real value in the individual self or the relational whole. If Nagarjuna meant to use his dialectic to prove this point, Hegel would have not been so far off the mark when he proclaimed that Buddhists worshipped nothingness. Instead of a progression from the affirmation of self to the affirmation of the Absolute, Nagarjuna affirms nothingness as the foundation of being. The Buddhist conception of the self, however, goes beyond the idea of a self in relation to spirit, history, or the other and makes room for an understanding of the self in relation to the tangible body. The invocation of the body, much like the paradigm of the Two Truths, is not meant to affirm the self as body. Attention to the body can, particularly through yoga, disrupt the notion that locating the self requires an examination into the self via metaphysical tools that create unity through abstract dogma. ${ }^{21}$

When readers of Nagarjuna focus on providing a different logical ground for unity in Buddhist philosophy, they often follow Hegel's model by positing truths about the nature of the self and being. The result is more a reworking of Nagarjuna in relation to Hegel than an engagement with Buddhism. Hegel, rather than Nagarjuna, remains the lead interpreter of Buddhism. ${ }^{22}$ Against this backdrop, Irigaray's appropriation of Buddhist philosophy is not so different from well-known scholars who are more acquainted with Buddhist texts. Her focus on yoga, however, does distinguish her from other scholars who put Hegel and Buddhism into dialogue with each other.

\section{Irigaray's Analysis of Dialectics}

Hegel's influence on Irigaray's reading of Buddhism is not surprising considering Hegel's reach in comparative thought and Irigaray's selfdescribed admiration for his work. ${ }^{23}$ Because Hegel marked the beginning of World History in the East, Irigaray shows herself to be an astute reader of Hegel by integrating an interpretation of Buddhism into her challenge to Hegelian philosophy. ${ }^{24}$ Indeed, her examination of Buddhism proves 
insightful, particularly when compared to Hegel's appraisal. Although Irigaray offers a more complimentary version of Buddhism than Hegel, her reading of it remains tied to his model. Irigaray's critique of the Buddhist dialectic even mirrors her challenge to Hegel's system.

In each, there is an attempt to erase difference, which for Irigaray is synonymous with nature. Irigaray believes that Hegel misses the mark when he asserts that negation of nature is the first step on the path to recognizing individuality, culture, and the Absolute. She, in contrast, believes that a self can develop in relation to nature and others and there is value in such a self. For Westerners, nature often represents what we share in common. Our natural qualities either do not work to distinguish one from another or only point to superficial qualities of difference. This tradition of Western thought, undoubtedly, contributes to Hegel's tendency to associate the self only with that which stands over and against nature.

Irigaray goes against the grain of Western philosophical history and praises Buddhists for cultivating a sense of self in relation to nature and other beings. She does not take this to be a sign, as Hegel does, that Buddhists completely lack a sense of self. Instead, she argues that Westerners could learn from Buddhists, who take cues from nature, rather than trying to suppress how nature shapes the self. ${ }^{25}$ Buddhist cultures, according to Irigaray, better understand breath and the ways it points to nature as the foundation of self. Our existence depends, after all, upon the natural act of breathing. Furthermore, the air we breathe connects us to nature as we breathe in what other humans, animals, and plants expel. ${ }^{26}$

Yet Buddhist philosophy, for Irigaray, also represents a fundamental misunderstanding of nature. She believes that Buddhists negate difference when they only recognize the ways nature points to relationality. Whereas Hegel believes Buddhists could not achieve individuality because they remained too close to nature, Irigaray believes Buddhist cultures would be more apt to embrace individuation if they were more in tune with nature. ${ }^{27}$ She suggests that Buddhists do not fully understand nature because they do not recognize that separation and individuation is inherent within nature. For her, nature shows how everything comes to be as it differentiates itself from another within a coupling. These examples include sexual difference, the emergence of spring from winter, and day from night. ${ }^{28}$ Irigaray further argues that paying attention to natural difference leads us to confront the fundamental difference between self and other that allows for a genuine relationship to develop. Only by first coming to understand the limits of self can we resist the urge to appropriate the other to self and to reduce everything to the same.

The greater point in Irigaray's analysis of Hegelian and Buddhist dialectics, therefore, is to affirm the primacy of natural difference. She suggests each system represents a version of a dialectic that works to negate natural difference by equating nature with sameness. In Hegel, she sees a philosopher who believes individuation comes about by leaving and negating 
nature. In Buddhism, she finds a philosophy that glosses over natural difference and sees movement into nature as renouncing individuality by integrating into the whole. She believes, however, that there is another way besides either negation of the other or integration into the other. Instead of following Hegel by sublating nature in order to arrive at self-consciousness, Irigaray suggests that we cultivate two types of consciousness. One recognizes that the self is separate from nature, family, and community; thus, allowing for individuation. The other recognizes that the self is part of a larger community. Westerners, however, tend to neglect or ignore such a self.

Irigaray's criticism of Buddhist cultures follows a common Western refrain. She believes that Buddhists must do more to cultivate an individual sense of self. Only through cultivating a sense of self as different from the other, she adds, can there be a better sense of community. ${ }^{29}$ Otherwise, the Buddhist model of interrelation-embracing the other at the expense of the self - is ineffective and even dangerous. By trying to erase the difference between self and other, the self can encroach, unconsciously, upon another's space and undermine the Buddhist call towards compassion for the other. Respect for the other depends on consciousness of difference between one's self and other. Reaching out to the other can quickly turn into overreach and domination.

Individuation, for Irigaray, is not only the foundation of being but also makes community possible. She argues that we, in the East and West, must foster a double subjectivity that is grounded in natural individuation, rather than a negation of nature or the self. A "double-I" 30 that recognizes selfidentity and community-identity can and must co-exist but this way of thinking and living must be cultivated by rethinking nature and recognizing that natural difference is the foundation of being and existence. Her encounter with Buddhism reminds us that natural difference cannot be negated without paying a hefty price.

Although Irigaray's reading of Buddhism helps her to differentiate her interpretation from others, Irigaray is not alone in thinking that the Buddhist system works through negation. This is a common enough view in Buddhist academic circles. Nagarjuna's Two Truths Doctrine, indeed, has generated a great deal of scholarship about the refutation of all philosophical positions, including the negation of difference. ${ }^{31}$ Still, Nagarjuna's enigmatic interpretation of Buddhist principles cannot be so easily reduced to negative propositions. He asserts, through his commentary on The Four Noble Truths, that everything both exists and does not exist. ${ }^{32}$ Such formulations do not allow scholars of his work simply to dismiss conventional truths about the self and reality. A close examination of his theories even shows that Buddhist philosophy, contrary to Irigaray's analysis, recognizes difference and individuation within nature.

T.R.V. Murti suggests that Nagarjuna's conventional truth or conventional nature relays the tendency to see the self as distinct from other beings and the world. ${ }^{33}$ Nagarjuna explains, in much the same manner as 
Irigaray after him, that other-existence is not possible without first identifying self-existence. ${ }^{34}$ Our first attempts to understand the self are made by distinguishing the self from the other and vice versa. Nagarjuna, therefore, speaks to the propensity to understand that things are independent by nature.$^{35}$ He intimates, contrary to Hegel, that natural consciousness leads us towards individuation rather than sinking into undifferentiated nothingness. On the other hand, Nagarjuna also challenges Irigaray's reading of Buddhism. While Irigaray calls for greater awareness of the divisions within nature, an underlying message of the Two Truths Doctrine is that the self grasps all too firmly the idea of natural cleavage and separation. Buddhists do not so easily forget the self in favor of the other, as Irigaray would seem to suggest. Still, Nagarjuna diverges from Irigaray because he does not seek to carve out greater space for the self and difference but seeks, rather, to find a method for moving beyond separation and division without reducing the individuated self to nothingness or superfluous illusion.

\section{Alternate Readings of Buddhism}

In trying to make sense of the seeming contradictions between subjective and absolute truth in Buddhism, some scholars seek to interrupt the Hegelian system by exploring the ways that logic could lead to disjunctive alternatives rather than the unity of disjunction. ${ }^{36}$ A philosophy of alternate standpoints imagines the emergence of alternate truths while not declaring the supremacy of a particular philosophical viewpoint. Hegel's Absolute Spirit, therefore, cannot unify various, contradictory positions. K. C. Bhattacharyya, instead, "asserts a plurality of determinate Truths and takes each truth to be an indetermination of alternative truths." 37 Different determinations can be logically sound but these truths cannot coincide with each other; they are incompatible with each other. ${ }^{38}$ Furthermore, this philosophy suggests that this incompatibility must be embraced while abandoning the need for relationality between standpoints.

Kalidas Bhattacharyya ${ }^{39}$ further challenges relationality through his logical unity of disjunction. Disjunction, for him, opens up the possibility of indifference between alternatives. Although Bhattacharyya suggests that there can be a rational relationship between Subjectivity and the Absolute, he believes such relationality can only occur if one is subordinate to the other. ${ }^{40}$ It is precisely the move to unite alternative positions or sublate contradictions that leads to the privileging of one philosophical position over others. Disjunction, in contrast, allows for alternate truths to arise without the necessity to proclaim the primacy or supremacy of one position over another. The unity of disjunction allows only for the excluding relationship between them. ${ }^{41}$ Whereas Irigaray believes that difference allows for relationality between individuals, Bhattacharyya suggests that parts do not necessarily have relationships to each other but, rather, have relationships to that which separates them or the exclusionary space between them. Even when Irigaray suggests that space exists between two, she implies relationality and 
receptivity in her description of a proximity that creates space for sharing. ${ }^{42}$ Bhattacharyya allows for non-awareness, indifference, and non-interaction of any particular other.

John Schroeder, in contrast, moves away from logic and suggests that Nagarjuna means to point to relationality through practice. ${ }^{43}$ Through exposing logical inconsistencies, Nagarjuna draws attention to the various non-hierarchal practices that help to develop greater compassion and lead the practitioner towards liberation. ${ }^{44}$ Nagarjuna, therefore, did not privilege one truth over another but meant to illuminate different paths that would help us better understand relationality. ${ }^{45}$ Conventional and ultimate truths both lead to greater reflection on interconnection. If meditation on the individuated self - or limits of the self as Irigaray suggests - and conventional truth leads us to grapple with the existence of others and our connections to them, this form of reflection has served its purpose. Meditation on ultimate truth, therefore, is no better or very different than meditation on conventional truth if it leads to a similar conclusion. Reflection on the second truth forces us, after all, to wrestle with the idea that the two truths cannot be separated conceptually from each other. If the practitioner can come to understand codependent origination through either of the two truths, the particular exercise is less important than the reflective practice. By focusing on the practice of meditation, ${ }^{46}$ Nagarjuna's texts could perhaps relay the ways Buddhists allow for meditation on the self and challenge the notion that Buddhists care only for the relational self.

Although Westerners often believe that Buddhists reject the individuated self in favor of the relational self, Nagarjuna's philosophy and an examination of Buddhist communities show that this is not the case. "At times, one takes away the person but does not take away the environment. At times, one takes away the environment but does not take away the person." 47 The self need not be thought always in relation to all else. Buddhists, accordingly, recognize that grasping interrelatedness is not always possible. Ingrid Jordt found, through her anthropological research, that most Buddhist practitioners realize that they are not able to resist self-identification, which is subdued through the meditation on the interdependent nature of reality. "It is generally assumed that when the meditation ends, so does the acute and penetrating concentrated insight." 48

Walpola Rahula further explains that desire for self-annihilation is but another manifestation of craving. ${ }^{49}$ The destruction of self should not be the driving force behind meditation, lest it become a preoccupation. ${ }^{50}$ Thich Nhat Hanh suggests that meditation is not about strain. "Too much effort is dangerous," ${ }^{51}$ he warns. Accordingly, when self-identification occurs, the response should not be to get rid of the thought but to acknowledge it. ${ }^{52}$ Meditation, instead, is the practice of responding to each moment, thought, and desire with equanimity. When the Buddha calls practitioners to make oneself into an island, ${ }^{53}$ he highlights how seeking refuge in oneself can be a way of restoring peace and calm. 


\section{Irigaray's Alternative Meditation Practices}

Placing too great an emphasis on the individuated self, to which Irigaray's critics can attest, can also be a problem. ${ }^{54}$ I suggest, however, that she mitigates this charge by articulating a means to apply the philosophy of alternative standpoints to the practice of meditation. Furthermore, Irigaray's analysis of Buddhism helps to bring practice into greater focus while dislodging the notion that there is a hierarchy of selves in Buddhism. Even though Irigaray insists that the focus on the individual self requires distance and withdrawal from the relational self, this does not mean that the relational self should never be the focus of meditation. Indeed, she praises Buddhists for the cultivation of the relational self. She suggests, instead, that it should not always be the focus of meditation. In other words, she allows for moments of non-relationality and alternation.

Though she resists the tendency to collapse the individual self into the relational self, her efforts to carve out a space for the individual is more a challenge to the Western conception of the self, which equates the individual with the male, than an attempt to foist Western individualism on Buddhist cultures. ${ }^{55}$ The greater problem in Western culture, according to Irigaray, is not so much that there is attention to the individual self but that the individual is always male. Accordingly, the relational self is often cast as feminine. In trying to make room for the seemingly non-existent feminine individual self, she seems to privilege the individuated self at the expense of the relational self.

Irigaray argues that the feminine self is too often associated with the relational self because female subjectivity is shaped by sacrifice and forgetting of the self. The feminine subject disappears or only has an identity insofar as she is joined to maleness. ${ }^{56}$ Because the feminine individual has never been fully realized, her philosophy works as a warning that women should not be too quick to cultivate a relational self. Once women begin to think of themselves as a relational self, it seems that there is no turning back or ability to recapture the individual feminine self. ${ }^{57}$ Such a reading, despite her praise for a relational identity, leads her challengers to believe that the individual identity is still superior.

By taking Irigaray's directive to cultivate the individuated and relational selves seriously, we can perhaps move away from her desire to whittle a space for the (feminine) individual self while creating a space for an application of Nagarjuna's thought that highlights fluctuation. Instead of sidestepping privilege or priority by showing the sameness that results from reflection on conventional or ultimate truth, Irigaray's analysis of meditation suggests that there is a distinction between the practices. If meditation on either conventional or ultimate reality can yield the desired result, the value of each self can be undercut. Irigaray, in contrast, emphasizes the difference between meditation on the individuated and relational selves. Just as one perspective of the self is not superior to another, meditation on only one form of the self 
is not adequate. If Nagarjuna's goal was to develop an attitude of nonattachment through a better understanding of emptiness, perhaps meditating on conventional and ultimate truth alternately could help practitioners from becoming too tied to a particular form of meditation. Alternation of meditation practices allows the fluctuation between the two selves to come into greater focus. ${ }^{58}$

1) Irigaray's philosophy hints at such a prescription for meditation. She suggests that we must meditate on the relation between self and others while also insisting that we need to withdraw from the other into the self. ${ }^{59}$ Instead of simultaneously maintaining the individuated and interdependent self, I believe that Irigaray offers a path to cultivate alternate selves. The subject, through meditative practices, sometimes works to renew the individuated self. Other times, the meditator focuses on realizing the relational self. More to the point, reflection on the other leads to greater understanding of the self. Attention to breath and the natural make us more aware of the connection with the other. Because she believes that it is necessary to pay attention to the different selves, the focus of meditation can alternate without ever completely losing touch with the truth(s) about the self.

Yet reflections on the self need not yield a stagnant self. Withdrawal into the self, as Irigaray prescribes, does not necessarily mean a retreat into fixed idealizations or be limited to meditations on the metaphysical. Selfwithdrawal can lead to reflections on changes within the self that might go unrecognized, if relationality received all of our attention. Without withdrawal into the self, change could be seen as simply a function of contact with the other. Meditation on the withdrawn self helps us to realize the indeterminate manifestations and possibilities of the self. The embodied nature of yoga also allows for an alternate meditation on interiority. Awareness of the self, via yoga, could help the practitioner to experience physical contact with oneself. Complex yoga postures are able to draw attention inwards because the touching of the inner body becomes perceptible. ${ }^{60}$

Such readings may be dismissed as too convenient and illogical but solving a conceptual problem between the self and whole is not the goal here. These interpretations, instead, draw out the ways Buddhism allows for cultivation of the individuated self, which is often overlooked. Meditations on individuated objects (a dish, an article of clothing, and even the self) are common practices just as meditations that point towards interconnectedness. ${ }^{61}$ Alternation in meditational focus is not only allowed but also part of the tradition, even if it is often overlooked. The practice of alternation, 
therefore, is consistent with the Buddhist practice of meditation and reflects an uncommon engagement with Nagarjuna's work.

\section{Conclusion}

Certainly, there will be those who believe that Irigaray needs to engage more with Buddhist scholarship, rather than leaning on insights gleaned through meditation practice, in order to properly reflect on Buddhism. Yet legendary descriptions about the Buddha's preference for practical aids over philosophical quandaries ${ }^{62}$ open a space for Irigaray's work on Buddhism. Emphasizing practice rather than philosophical precepts also affirms the idea that the fruits of Buddhism can be found through meditative practice. That Irigaray could attain such perception about the self, reality, and relationality primarily through meditation only reinforces the value of this central Buddhist practice.

Although practicing meditation in alternation may not resolve the logical puzzle of the self, such a method can perhaps reinforce the idea that cultivation of the self does not progress in one direction. Meditation on the individual self does not signal an unenlightened mind, unable to grasp the ultimate truth, as some readings of Buddhism would suggest. Nor does the recognition of the individuated self, as Hegel argues, represent a movement into a more mature stage of being that has clearly, fully, and permanently separated from nature. Instead, the self emerges in myriad forms within the fluctuations of consciousness. Alternation of meditation can help us to approach the self, as island or wave in the ocean, ${ }^{63}$ with renewed attention.

1 Young, Iris Marion, Intersecting Voices: Dilemmas in Gender, Political Philosophy, and Policy (Princeton: Princeton University Press, 1997), 56. Originally quoted in LaCaze, Marguerite, "The Encounter between Wonder and Generosity," Hypatia vol. 17, no. 3 (2002), 8.

2 Joy, Morny, Divine Love (Manchester: Manchester University Press, 2007), 195.

${ }^{3}$ Schwab problematizes Irigaray's (and her own) interest in yoga but affirms its transformative power, physically and philosophically. Schwab, Gail, "Beyond the Vertical and the Horizontal," in Thinking with Irigaray, eds. Mary C. Rawlinson, Sabrina L. Hom, and Serene J. Khader (Albany: SUNY Press, 2011), 86-87.

${ }^{4}$ Like Hegel, Nagarjuna exerts great influence on his respective tradition. Jay Garfield and Graham Priest believe that Nagarjuna's work has had more influence on Eastern thought than any other thinker in any given field. Garfield, Jay and Priest, Graham. "Nagarjuna and the Limits of Thought," Philosophy East and West vol. 53, no. 1 (2003), 1.

${ }^{5}$ Hegel, G.W.F., Philosophy of History, trans. John Sibree (Kitchener: Batoche Books, 2001), 128.

${ }^{6}$ Hegel, G.W.F., Philosophy of Mind, trans. A.V. Miller (Oxford: Oxford University Press, 1971), 43.

${ }^{7}$ Hegel, G.W.F., Lectures on the Philosophy of Religion, vol. 2, trans. Robert Brown, Peter Hodgson, and Jon M. Stewart, ed. Peter Hodgson (Berkeley: University of California Press, 1995-98), 564.

${ }^{8}$ Hegel, G.W.F., Phenomenology of Spirit. trans. A.V. Miller (Oxford: Oxford University Press, 1977), 51. 
${ }^{9}$ Many thinkers suggest that Hegel provides one of the earliest philosophical accounts of Buddhism to the Western world. His analysis that Buddhism is a religion of nothingness, according to Roger-Pol Droit, is often misunderstood to be a charge against Buddhist philosophy. Droit believes that Hegel gives a more positive account than his contemporaries. Droit, Roger-Pol, The Cult of Nothingness: The Philosophers and the Buddha, trans. David Streight and Pamela Vohnson (Chapel Hill: University of North Carolina, 2003), 67.

10 Droit, Cult of Nothingness, 67.

11 Dumoulin, Heinrich, "Buddhism and Nineteenth-Century German Philosophy," The Journal of History of Ideas vol. 42, no. 3 (1981), 462.

12 Droit, Cult of Nothingness, 60-65.

13 The comparisons between these two seem inevitable considering Hegel's philosophy influence on Western thought and Nagarjuna's influence on Eastern thought.

${ }^{14}$ Garfield, Jay L., The Fundamental Wisdom of the Middle Way: Nagarjuna's Mulamadhyamakakarika (New York: Oxford University Press, 1995), 68.

15 Nick Gier relays the commonalities between the negation in Hegel and Nagarjuna but notes that Hegel's dialectic is real while the Buddhist dialectic is mental. Hegel inscribes historical progress within his dialectic. Buddhism, in contrast, simply relays the path of consciousness as it moves towards greater enlightenment. Gier, Nick, "Dialectic East and West," Indian Philosophical Quarterly vol.10, no. 2 (1983), 211.

${ }^{16}$ Nanajaviko discusses the unfortunate tendency to interpret Nagarjuna through Hegel. Nanajaviko, Bhikku, “Hegel and Indian Philosophy," Indian Philosophical Quarterly vol. 3 (1998), 307.

17 Schroeder, John, "Nagarjuna and the Doctrine of Skillful Means," Philosophy East and West vol. 50, no. 4 (2000), 560.

18 Nanajivako, "Hegel and Indian Philosophy," 296. See also Tillich, Paul, Christianity and the Encounter with World Religions. (New York: Columbia University Press, 1963), 36. Originally quoted by Nanajivako, "Hegel and Indian Philosophy," 320.

19 Lindtner, Christian, Master of Wisdom. (New York: Dharma Publishing, 1986), 162. Originally quoted in Schroeder, John, "Nagarjuna and the Doctrine of Skillful Means," 560.

20 Nanajaviko argues that this is the case for famed scholar, T.R.V. Murti, Nanajaviko, "Hegel and Indian Philosophy," 309. See also Murti, T.R.V. Murti, The Central Philosophy of Buddhism. (London: Allen and Unwin, 1960), 48.

21 Shlomo Biderman, Crossing Horizons: World, Self, and Language in Indian Thought (New York: Columbia University Press, 2013), 206.

22 Bhikku Nanajaviko argues that this is the case for scholars in the East as well. Nanajaviko, "Hegel and Indian Philosophy," 320. As we will see, The Philosophy of Kalidas Bhattacharyya gives examples of how Indian scholars tried to develop an alternative to Hegel's Absolute. Krishna, Daya. "Kalidas Bhattarcharyya and the Philosophy of Alternation," in The Philosophy of Kalidas Bhattarcharyya. ed. Daya Krishna (Ganeshkhund: University of Poona Publishing, 1985), 22.

${ }^{23}$ Burke, Karen I., "Masculine and Feminine Approaches to Nature" in Luce Irigaray: Teaching. eds. Luce Irigaray and Mary Green (New York: Continuum, 2008), 191.

24 Tim Morton suggests that Hegel intuited a sexual and nihilistic aspect in the naturalistic Buddhist religion through the image of the toe-sucking Buddha. Morton, Tim, "Hegel on Buddhism," Romanticism and Buddhism, (February 2007), accessed February 19, 2013, http://www.rc.umd.edu/praxis/buddhism/morton/morton.html. Sex and nature are, of course, themes that Irigaray further fleshes out.

${ }^{25}$ Although Hegel believes the subject must overcome nature to develop the self, Irigaray argues that nature is always at the foundation of the self. Stone, Alison. "The Sex of Nature: A Reinterpretation of Irigaray's Metaphysics and Political Thought,” Hypatia 18, no. 3 (2009), 175176.

${ }^{26}$ Irigaray's ideas about breath prompt Irving Goh to propose that it is appropriate to think about our relationship to others in terms of the reject rather than the subject. Goh, Irving, "Touch Today: From Subject to Reject," SubStance vol. 40, no. 3 (2011), 123-126. 
27 Her analysis of Buddhism does not yield a drastically different view of Buddhism. She seems to concur with Hegel that Buddhists, generally, do not have an adequate conception of the individuated self, albeit for a different reason.

${ }^{28}$ Stone, "Sex of Nature," 63. William Robert also discusses how Irigaray forms her concept of nature in relation to Hegel. Where he believes sex is a part of nature, she believes that nature is always sexed. Robert, William. "Antigone's Nature," Hypatia vol. 25, no. 2 (2010), 412-436.

Robinson, Robert H., "Did Nagarjuna Really Refute All Philosophical Views?" Journal of Indian Philosophy vol. 22, no.3 (2010), 424.

${ }^{29}$ Irigaray, Luce, Between East and West: From Singularity to Community, trans. Stephen Pluhacek (New York: Columbia University Press, 2002), 74-75.

30 Irigaray, Between East and West, 97-98.

31 Many scholars have used Nagarjuna's work to refute any and all philosophical positions. See Robinson, Robert H., "Did Nagarjuna Really Refute All Philosophical Views?" Journal of Indian Philosophy vol. 22, no.3 (1972), 325-331. For this reason, the first of Nagarjuna's two truths, which gives value to conventional views, does not receive as much attention. Nagarjuna's enigmatic writings include affirmation of existence and being of all things.

32 Garfield and Priest, "Nagrajuna and the Limits of Thought," 1.

${ }^{33}$ Murti, T.R.V., "Samvrti and Paramartha in Madhyamika and Advaita Vedanta," in The Problem of Two Truths in Buddhism and Vedanta, ed. Mervyn Sprung (Boston: D. Reidel Publishing Company, 1973), 17. He believes, contrary to Irigaray, that thinking difference eventually has to be overcome.

${ }^{34}$ Velez de Cea. Abraham, "Emptiness in the Pali Suttas and the Questions of Nagarjuna's Orthodoxy," Philosophy East and West vol. 55 no. 4 (2005), 517.

35 Schroeder, "Nagarjuna and the Doctrine of Skillful Means," 572.

${ }^{36}$ Sharma, K.L., "A Step beyond K. C. Bhattarcharyya," in The Philosophy of Kalidas Bhattarcharyya. Ed. Daya Krishna. (Ganeshkhund: University of Poona Publishing, 1985), 12.

${ }^{37}$ Sharma, "A Step beyond," 7. See also Bhattacharyya, K.C., Studies in Philosophy (Calcutta: Motilal Books, 1983).

${ }^{38}$ Sharma, "A Step beyond," 10.

${ }^{39} \mathrm{His}$ philosophy is an extension of work done by his father, K.C. Bhattacharyya. See Sharma, "A Step beyond," 7. Although his father began to build his insights on Jainism, the philosophy of alternate standpoints was also thought in conjunction with Buddhist and Hegelian philosophy. See Sharma, "A Step beyond," 22. Considering Irigaray's self-proclaimed interest in Hindic traditions and their influence on Buddhism, Bhattacharyya could be a valuable resource for her. Irigaray, "Between East and West, 21. See also Irigaray's response to Morny Joy. Joy, Divine Love, 200.

${ }^{40}$ Krishna, "Kalidas Bhattarcharyya," 29. See also Bhattacharyya, Kalidas, Alternative Standpoints in Philosophy (Calcutta: Das Gupta and Co., Ltd., 1953).

${ }^{41}$ Sharma, "A Step beyond," 9.

${ }^{42}$ Irigaray considers how the placenta serves as an apt metaphor for the space between beings (mother and child, in this case) that separates but allows for sharing. Irigaray, Luce, Je, Tu, Nous (New York: Routledge, 1993), 41. She also uses the proximity of speech to elucidate withdrawal and relationality. See Irigaray, Luce, The Way of Love, trans. Heidi Bostic and Stephen Pluhacek (New York: Continuum Press 2000), 32-33.

${ }^{43}$ Schroeder argues that an examination of practice also has philosophical value, even if other scholars tend to believe that only studies of Nagarjuna's logic yield philosophical analyses.

${ }^{44}$ Schroeder, "Nagarjuna and the Doctrine of Skillful Means," 562.

45 Nagarjuna intended the doctrine to be an aid to contemplation but they turned into a set of speculations about the ultimate identity and truth. Velez de Cea, "Emptiness," 518.

46 Nancy McCagney argues that emptiness refers to meditative attainment. McCagney, Nancy, Nagarjuna and the Philosophy of Openness (New York: Rowman and Littlefield, 1997), 57. Originally cited in Velez de Cea, "Emptiness," 508. 
${ }^{47}$ Bernard Faure suggests that these words from a Chinese Buddhist Master reflect the influence of Nagarjuna's Madhyamika school. Faure, Bernard, Double Exposure: Cutting Across Buddhist and Western Discourse, trans. Janet Lloyd (Stanford: Stanford University Press, 2004), 94. See also Watson, Burton, trans., The Zen Teachings of Master Lin-chi: A Translation of the Lin-chi lu (New York: Columbia University Press, 1993), 21.

48 Jordt, Ingrid, “Defining a True Buddhist: Meditation and Knowledge Formation in Burma," Ethnology vol. 45, no. 3 (2006), 202.

${ }^{49}$ Rahula, Walpola, What the Buddha Taught (New York: Grove Press, 1974), 29.

${ }^{50}$ This applies to the desire of the self as well.

${ }^{51}$ Nhat Hanh, Thich, The Miracle of Mindfulness, trans. Mobi Ho. (Boston: Beacon Press, 1987), 18.

52 Nhat Hanh, Miracle, 56.

${ }^{53}$ Nhat Hanh, Thich, Living Buddha, Living Christ (New York: Riverhead, 1995), 122-123.

${ }^{54}$ Goh, "Touch Today," 123.

55 She does not believe that the privilege of the male is solely a Western problem. Irigaray describes her dismay at the patriarchal attitudes that she encountered during yoga courses. Irigaray, Between East and West, 67.

56 Irigaray, Luce, I Love to You: Sketch of a Possible Felicity in History, trans. Alison Martin (New York: Routledge, 1996), 56.

57 This is not the case for Western men because their individuality is believed to be secure.

58 Faure believes that fluctuation, more than anything else, is at the roof of Nagarjuna's thought. Faure, Double Exposure, 96.

59 Irigaray, The Way of Love , 101.

60 Sunder Sarukkai, “Inside/Outside: Merleau-Ponty/Yoga,” Philosophy East and West vol. 52, no. 4 (2002), 472.

${ }^{61}$ Nhat Hanh, Miracle, 84-86.

62 Rahula, What the Buddha Taught, 14.

63 This image invokes the interrelation. Nhat Hanh, Thich, The Heart of Understanding. ed. Peter Levitt (Berkeley: Parallax, 1988), 13. 